palliation to successful transplantation as well as a possible alternative treatment to transplantation in selected children and adults. Quality of life and cost analyses, as well as longer follow up studies are needed to determine the best treatment for patients with primary pulmonary hypertension.

ROBYN J BARST

Division of Pediatric Cardiology,

Columbia University College of Physicians and Surgeons,

3959 Broadway BH 262N,

New York, NY 10032, USA

1 Romberg E. Uver sklerose der lungenarterien. Dtsch Arch Klin Med 1891; 48:197.

Dresdale DT, Schultz M, Michtom RJ. Primary pulmonary hypertension. Am $\mathcal{F}$ Med 1951;11:686-705.

3 D'Alonzo GE, Barst RJ, Ayres SM, Bergofsky EH, Brundage BH, Detre

KM, et al. Survival in patients with primary pulmonary hypertension: KM, et al. Survival in patients with primary pulmonary hypertension: results

4 Rubin LJ, Mendoza J, Hood M, McGoon M, Barst RJ, Williams WB, et al. Treatment of primary pulmonary hypertension with continuous intravenous prostacyclin (epoprostenol): results of a randomised trial. Ann Intern Med 1994;112:485-91.

5 Barst RJ, Rubin LJ, McGoon MD, Caldwell EJ, Long WA, Levy PS. Survival in primary pulmonary hypertension with long-term continuous intravenous prostacyclin. Ann Intern Med 1994;121:409-15.
6 Barst RJ, Rubin LJ, Long WA, McGoon MD, Rich S, Badesch DB, et al. A comparison of continuous intravenous epoprostenol (prostacyclin) with comparison of continuous intravenous epoprostenol (prostacyclin) with Med 1996;334:296-301.

7 Fuster V, Steele PM, Edwards WD, Gersh BJ, McGoon MD, Frye RL. Primary pulmonary hypertension: natural history and the importance of thrombosis. Circulation 1984;70:580-7.

8 Rich S, Kaufmann E, Levy PS. The effect of high doses of calcium-channe blockers on survival in primary pulmonary hypertension. $N \mathrm{Engl} f \mathrm{Med}$ 1992;327:76-81.

9 Barst RJ. Pharmacologically induced pulmonary vasodilatation in children and young adults with primary pulmonary hypertension. Chest 1986 89:497-503.

10 Moncada S, Vane RJ. Arachidoic acid metabolites and the interactions between platelets and blood-vessel walls. $N$ Engl $\mathcal{f}$ Med 1979;300: $1142-7$.

11 Higenbottam TW, Wheeldon D, Wells FC, Wallwork J. Long-term treatment of primary pulmonary hypertension with continuous intravenous ment of primary pulmonary hypertension with con

12 Jones DK, Higenbottam TW, Wallwork J. Treatment of primary pulmonary hypertension with intravenous epoprostenol (prostacyclin). $B r$ monary hypertension with

13 Higenbottam TW, Spiegelhalter D, Scott JP, Fuster V, Dinh-Xuan AT Caine $\mathrm{N}$, et al. Prostacyclin (epoprostenol) and heart-lung transplantaCaine $\mathrm{N}$, et al. Prostacyclin (epoprostenol) and heart-lung transplanta-
tion as treatments for severe pulmonary hypertension. Br Heart $f$ 1993; 70:366-70.

14 Pasque MK, Trulock EP, Cooper JD, Triantafilou AN, Huddelston CB, Rosenbloom $\mathrm{M}$, et al. Single lung transplantation for pulmonary hypertension. Circulation 1995;92:2252-8.

15 Kerstein D, Levy PS, Hsu DT, Hordorf AJ, Gersony WM, Barst RJ. Blade balloon atrial septostomy in patients with severe primary pulmonary hypertension. Circulation 1995;91:2028-35.

\title{
STAMPS IN CARDIOLOGY
}

\section{Ferdinand Sauerbruch (1875-1951)}

Germany (West Berlin) issued this single 50 pfennig stamp in 1975 to commemorate the centenary of the birth of Sauerbruch. Other medical personalities occasionally featured on stamps from West Berlin have included Virchow (1952), von Humboldt (1952, 1985), Koch (1960), and von Graefe (1978).

Ferdinand Sauerbruch was a great pioneer of both thoracic and cardiac surgery who worked first in Zurich and Munich and then from 1928 at the Charité Hospital in Berlin. $\mathrm{He}$ invented inflow occlusion of the heart as a way of making it easier to suture cardiac lacerations. His method, described in 1907, was to compress the base of the heart and the venae cavae with two fingers of the same hand, or to press on the right heart with the thumb and finger. In 1912 he performed pulmonary embolectomy using the method described in 1908 by Trendelenburg. As was usual with this operation, which was still being done 20 years later, his patient died. In 1913 he was the first surgeon to resect the pericardium for constrictive pericarditis and, despite his concern that he had freed only the right ventricle, his patient was well 11 years later. In 1931 he became the first to operate, albeit by mistake, on a cardiac aneurysm. The patient had a mediastinal mass which spurted blood into his face when it was incised. He inserted a finger and found a hole surrounded by a resilient ring beyond which was a cardiac chamber which seemed to be the right ventricle. He closed the hole with silk sutures "tying knots we could not see". The patient made a complete recovery. But perhaps he is best known for the remarkable differential pressure chamber which he devised in 1905 and which permitted the thoracic cavity to be opened without the lung collapsing. Initially his chief, Professor

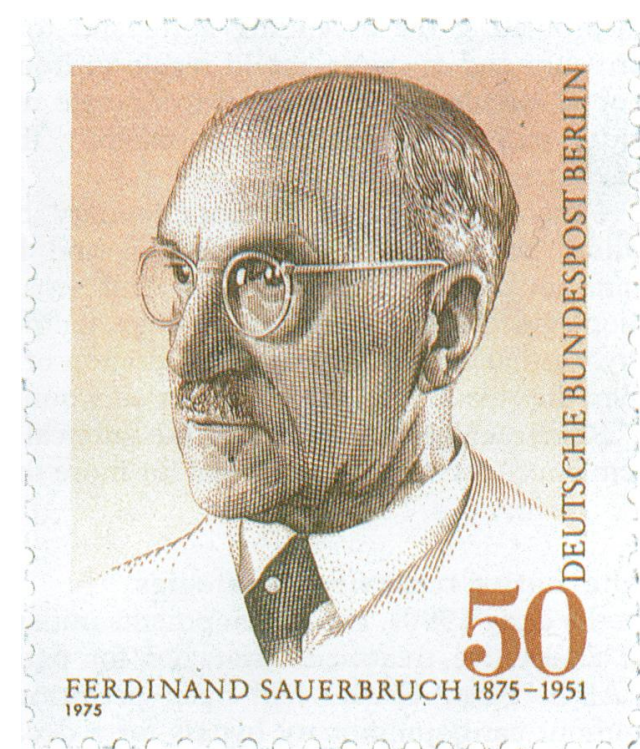

von Mikulicz, called him a charlatan, but later he fully supported his work. Laurence O'Shaughnessy, the British pioneer of cardiac revascularisation studied under him. Sauerbruch's autobiography in 1953, $A$ Surgeon's Life, reveals a dynamic man, with deep concerns for his patients and colleagues. It is full of interesting stories ranging from a chest operation on the daughter of Lord Cavendish-Bentinck, removing a tooth from the young Lenin, who could not afford a dentist, to exciting Hitler's jealousy by making friends with the dog Hitler thought was devoted to him. 